\title{
Curative Tourism Development in Egypt: Case of Al-Wadi Al-Jadid Governorate
}

\section{Tamer Hamdy Ayad}

\author{
Lecturer - Tourism Studies Department \\ Faculty of Tourism and Hotels, Suez Canal University
}

\begin{abstract}
Curative tourism is one of the fastest growing sub-sectors of the international tourism industry, due to the increasing stress from life and work; it has become an important issue for modern people to release stress and pursuit health in everyday life and leisure time. Medical Tourism Association stated that health tourism has a constant annual increase of $20 \%$ with a considerable demand potential, this has boosted the development of health and well-being tourism activities all over the world. Having al-Wadi al-Jadid Governorate as a case study, which was pointed out as one of the important strategic tourism development site in Egypt, this paper aims to examine the development for potential of Curative Tourism in al-Wadi al-Jadid Governorate by adopting a quantitative and a qualitative research method to achieve the research objectives.
\end{abstract}

Key Words: Curative Tourism, Tourism Development, Al-Wadi Al-Jadid Governorate.

\section{Introduction}

Traveling abroad for one's health has a long history. Throughout the ages, the patients have been traveled abroad for care because of a lack of access to services that were unavailable or unapproved or prohibited or restricted in their home countries. However, it was not until the early 21st Century that medical tourism experienced a major breakthrough, becoming an industry in its own right, and that the term medical tourism came into common use. Ever since, there has also been a manifest trend at work, in that patients from developed countries have been travelling to developing countries (Skowron and Skowron, 2014).

Many factors increase the world demand for health tourism such as avoidance from long line waiting list for treatment in their own country, getting proper treatment in terms of technology and quality standards, lower cost per treatment, high quality of hospitality and recreation and visiting interesting places (Rouhollah and Dirin, 2013).

Many countries are interested in curative tourism especially those that have curative resources, where they develop their infra and superstructures to cope with the vast international demand. 
This attention is due to the big importance of curative tourism in completing the medical treatment, which the patient receives in hospitals or medical centers. These because curative therapy helps to achieve a better result from medical treatment, for example, those who had fractures and they were operated in hospitals need to use therapeutic waters to enhance the degree of recovery (Harahsheh, 2002).

In Egypt, the economic potential of tourism, as a key driver of growth and development, is based on the competitive advantages that the country has in its natural and cultural resources, which should generate various types of tourism, such as curative tourism, educational, Rural and Eco Tourism. The curative tourism development is of great importance and has a well defined concept in European countries and other developed nations. Unfortunately, it has not been taken up seriously in the developing nations like Egypt. So this paper aims to examine the potential of Curative Tourism in al-Wadi al-Jadid Governorate and suggests strategies for the development of Curative Tourism in the area.

\section{Definition of Curative Tourism:}

Variety of definitions is used in order to characterize health tourism. Hoobin (2011) mentioned that World Tourism Organization (WTO) defined Health Tourism as a form of tourism to preserve, enhance and retrieve physical and mental health of individuals that takes over 24 hours and less than a year. Health Tourism divides into three types: Wellness Tourism; Curative Tourism; Medical Tourism.

Wellness Tourism defined as travelling to health villages and areas having natural hot/warm mineral water sources to get rid of the stresses of everyday life and revitalizing without intervention and medical monitoring and in the cases where tourist has not clear physical illness is called wellness tourism ( Hoobin, 2011; Harahsheh, 2002 ).

Curative Tourism defined as travelling for using the natural curative resources ( Mineral water, salt, mud, etc ) for the treatment of certain diseases or livelihood recovery under the supervision and intervention of a therapist ( Hoobin, 2011 ).

Medical Tourism defined as a journey carried out to treat physical illness or a surgery done under the supervision of doctors in hospitals and medical centers. In this type of health tourism the patient may require the use spaces and curative tourism services such as spas (Ildoromi and Sefidi, 2011 ).

\section{World Health Tourism Market:}

The world population is aging and becoming more affluent at rates that surpass the availability of quality healthcare resources. In addition, out-of-pocket medical costs of critical and elective procedures continue to rise, while nations offering universal care are faced with ever-increasing resource burdens. These drivers are forcing patients to pursue cross-border healthcare options either to save money or to avoid long waits for treatment. The worldwide medical tourism market 
is growing at a rate of $15-25 \%$, with rates highest in North, Southeast and South Asia (Patients beyond Borders, 2018). As of 2008, health tourism as a national industry has been recognized by 50 countries (Gahlinger, 2008).

Patients Beyond Borders' editors ( 2018 ) believe the health tourism market size is USD 45.5 - 72 billion, based on approximately 14 up to 16 million cross-border patients worldwide spending an average of USD 3,800 - 6,000 per visit, including all medically-related costs, cross-border and local transport, inpatient stay and accommodations. Only 1,400,000 Americans travelled outside the US for medical care during 2017.

By examining cross-border spending for medical services in more than 176 countries, to determine the world top successful destinations in Health Tourism according cross-border spending, the United States was found to be the single largest hub for medical tourism. Thailand, Singapore, Germany, Korea, and Spain are quickly catching up, increasingly attracting visitors from around the world, according to an analysis of financial transaction data (Medical Tourism Association, 2017 ), while the world top successful destinations in Health Tourism according to medical specialties in which these countries excel, are Thailand for Plastic Surgery, Malaysia for Dermatology, Germany for Oncology, Costa Rica for Dental Care, Mexico for Dentistry, Turkey for Eye Specialists, United Arab Emirates for Bariatric Surgery, Poland for Dental Implant, Hungary for Teeth Whitening, Brazil for Liposuction, and Czech Republic for Medicinal Spas ( Joint Commission International, 2018 ).

In Middle East area, Jordan appears as one of the best health care system in the region. The World Bank ranks Jordan as a top medical tourism destination in the Middle East and North Africa (World Bank, 2017). In addition to good health care system, Jordan enjoys varied natural resources for wellness tourism such as the assortment and abundance of hydrothermal mineral water, curative mud and Dead Sea. Also it offers traditional therapies, faith/spiritual healing, alternative medicine, popular medicine and geothermal hot springs, Jordan presents a single basket of medical health curative tourism services to an individual that is hard to be matched by other countries, which makes Jordan as a suitable place for health tourism throughout the year ( Ababneh, 2017 ). On 2014, Jordan was awarded Medical Destination of the Year by IMTJ Medical Travel Awards for attracting 250,000 international patients as tourists and generating a revenue of more than $\$ 1$ billion, and it has 10 hospitals in the country are JCI Accredited. Mainly it's catering to medical tourists primarily from Iraq, Syria, Yemen and other countries in the Middle East region with prices are rated to be around $10 \%$ of the costs experienced in the US (Medical Tourism Association, 2018a).

While in Egypt. Healthcare system consists of both, a private and a public sector, with government-run facilities providing treatment free of charge. The health insurance organization offers public healthcare, which covers more than half of the Egyptians, Government also allows the private insurance options, as well as private healthcare providers and medical facilities to coexist. Still, the public health insurance system has a reputation of being of poor quality (Medical Tourism Association, 2018b). As for Natural therapy or Natural curative tourism in Egypt, there is only one bright point, which is Menaville Resort in Safaga, it has become, over the past few years, 
a world-renowned Red Sea destination for climate therapy patients. People suffering from diseases such as psoriasis and rheumatoid arthritis (Egyptian Tourism Authority, 2018)

\section{The Case Study Area:}

Al-Wadi al-Jadid "New Valley" is the biggest governorate in Egypt, covering an area of 440,098 square kilometers, about \%44 of the total surface area of Egypt. It extends in the north as far as Marsa Matrouh, Giza and Minya governorates, in the south as far as Sudan and in the west as far as Libya. In the east it is coterminous with the governorates of Assiut, Sohag, Qena, Luxor and Aswan ( Egypt State Information Service, 2017 \& New Valley Governorate, 2017 ).

Al-Wadi al-Jadid "New Valley" Governorate consists of three oases, Kharga, Farafra and Dakhla. it comprises 4 main cities ( Kharga, Paris, Mut and Farafra ), 30 rural local units and 41 belonging villages ( Ayad, 2008 ). Figure (1) presents the borders and the administrative division of New Valley Governorate.

Figure (1): The borders of Al Wadi al Jadid Governorate.

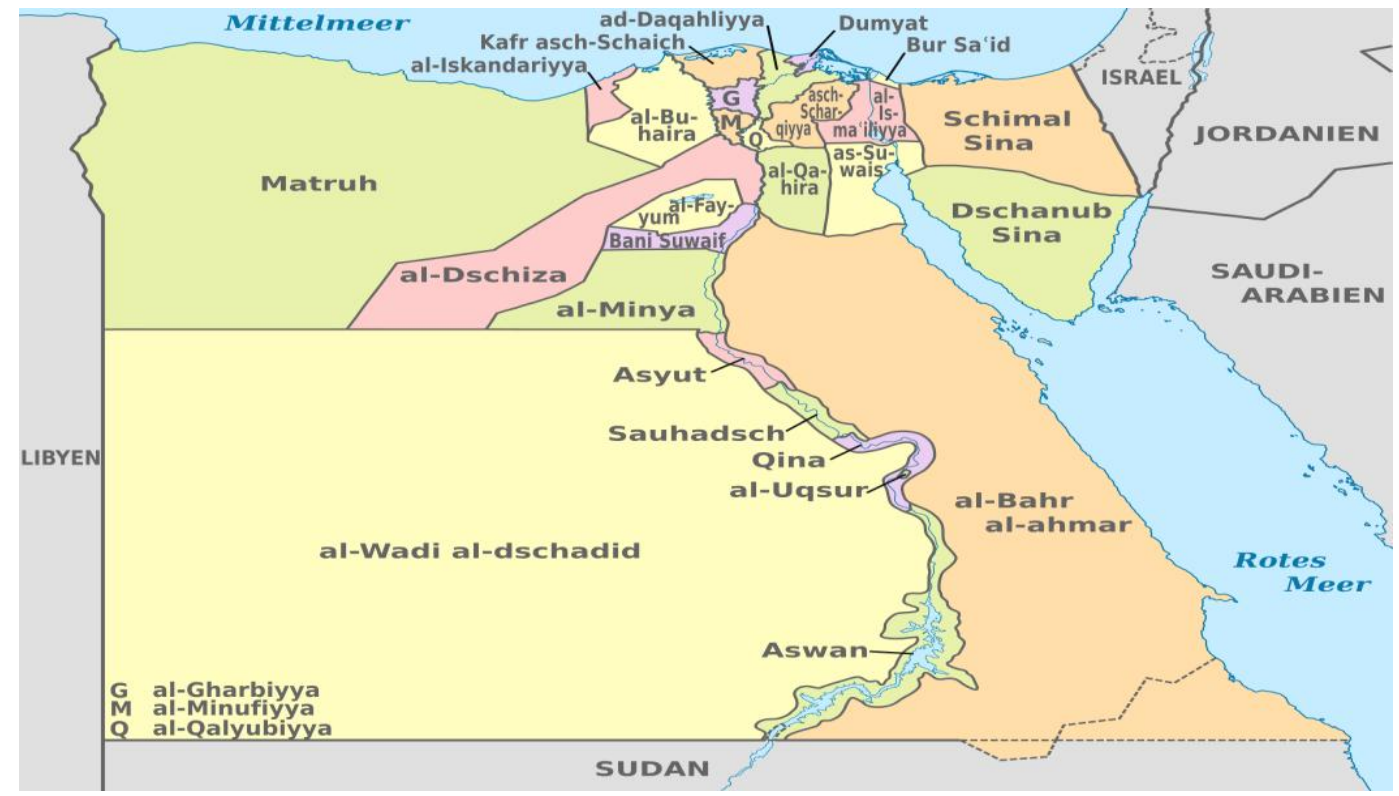

Source: Wikimedia Commons, 2017.

Regarding the economical situation in the governorate, the total public investments targeted in the new Valley Governorate in accordance with the fiscal year plan 2017/2016 about 3.4 billion pounds (US\$172 Million). Real estate sector and crude oil sector are the dominating sectors (Ministry of Planning, 2017). The tourism sector is witnessing remarkable growth with 25 investment projects during 2017, 7 projects at Kharga, 12 projects at Dakhla, 2 projects at Paris, and 4 projects at Farafra (New Valley Governorate, 2017). 


\section{Al-Wadi al-Jadid Governorate Natural Components:}

Al-Wadi al-Jadid "New Valley" Governorate is rich in natural components, which can be used to create new patterns of Tourism activities, such as Natural Hot Springs, Unpolluted Pure Environment, Sand Dunes, Depressions, Mountains, National Parks, Natural vegetation and wild herbs, Fauna, as well as a great variety of landscapes. In addition to historical and cultural heritage, which is unique in the world and its people's Social Features, such as distinct habits and traditions, Bedouin folklore, and local handmade products ( Ayad, 2008 ).

There are 752 curative sites in New Valley Governorate, where there are 564 sites in Dakhla Oases and 188 sites in Kharga oases of total 1356 curative sites all over the country, which represent $56 \%$ of the total curative sites for treatment of burials in the sand and treatment by sulfur water in Egypt, which has unique properties that can heal many diseases such as Skin diseases (scabies, eczema, acne, psoriasis) Gout, Obesity, metabolic disorders, locomotors system diseases, Inflammatory nerves, stiff joints, rheumatoid, bone infections ( Danida et al, 2007; State Ministry of Environment and New Valley Governorate, 2008 \& 2017 ).

The New Valley climate is dry desert climate, State Ministry of Environment and New Valley Governorate (2008 \& 2017) stated that Al-Wadi al-Jadid Governorate enjoys a curative climate and the most important factors may be illustrated as follows:

- Rainfall is almost scarce throughout the year, not exceeding $4 \mathrm{~mm} /$ year.

- Average annual temperature is 23 degree Celsius.

- Average relative annual humidity is $35.5 \%$.

- Average annual wind speed is $6 \mathrm{~km} / \mathrm{hour}$.

\section{Methodology:}

\section{Research Population:}

The population of this research is a finite population, which can be easily determined, 12 hotels and eco lodges ( 4 hotels in Kharga, 3 hotels in Dakhla, 3 hotels in Farafra, and 2 hotels in Paris ), 6 licensed travel agencies in Al Wadi al Jadid Governorate, 4 licensed travel agencies in Cairo, which have big share of eco-tourism business in western desert, Egyptian Tourism Authority office in Kharga, Tourism office at Al Wadi al Jadid Governorate, one Specialist in the treatment by burial in the sand, and three locals from Al-Rashayda and Al-Adaresa tribes, who are specialists in Bedouin environmental treatment. So total of population is 28 members, who are representing all private, and governmental tourism stakeholders in Al Wadi al Jadid Governorate, and particularly who are dealing with curative tourism topic. Accordingly, complete count method was adopted in this study as a data collection method.

\section{Data collection:}

Secondary data were collected from the official documents, researches and reports about Al Wadi al Jadid Governorate, primary data were collected by interviews with private and governmental 
stakeholders.

A questionnaire was designed to achieve the research objectives and a total of 28 stakeholders were interviewed. The questionnaire consists of three parts, the first part to assess the potential of curative tourism in Al Wadi al Jadid Governorate, respondents were asked to assess 15 items related to curative tourism from poor to excellent, such as environment, accommodation, infrastructure, climate, natural water springs, sulfur hot sand ; the second concerns the importance of developing curative tourism in Al-Wadi al-Jadid Governorate, respondents were asked to determine the importance of developing curative tourism and its economical, social and environmental impact on the local community in Al-Wadi al-Jadid Governorate, on a five-point Likert scale, ranging from strongly disagree (1) to strongly agree (5). The third part contains open questions to know the viewpoint of tourism stakeholders about the strengths, weakness of AlWadi al-Jadid Governorate as a curative tourism destination, and to know the opportunities and threats to develop curative tourism in this area.

\section{Analysis Techniques:}

Quantitative data were analyzed with the aid of Statistical Package for Social Sciences (SPSS) version 17 and Excel Spread Sheet in Office 2007. Frequency distribution tables and computation of proportions in percentage were used to analyze the tourism stakeholders assessment of the potential (Natural and Artificial) of Curative tourism in Al-Wadi al-Jadid Governorate and descriptive statistics to descrip the importance and impacts of developing curative tourism in AlWadi al-Jadid Governorate.

Qualitative data were analyzed by using strategic analytical tool, which is SWOT analysis, to help achieving the aim of this paper, to suggest strategies for the development of Curative Tourism in the area, examines the potential of Curative Tourism in al-Wadi al-Jadid Governorate, by presenting the strengths and weaknesses, as internal environment characteristics for curative tourism development in Al-Wadi al-Jadid Governorate, and marks out the opportunities and the threats of the external environment for developing curative tourism in the study area.

\section{Analysis and Results:}

\section{1- Distribution of frequency of Tourism Stakeholders point of view:}

Table (1) explains point of view of tourism stakeholders to assess the potential of curative tourism in Al-Wadi al-Jadid Governorate according to Likert Scale.

Table (1): Assessment the potential of curative tourism

\begin{tabular}{|c|c|c|c|c|c|c|c|c|c|c|}
\hline \multirow[t]{2}{*}{ Item } & \multicolumn{2}{|c|}{1} & \multicolumn{2}{|c|}{2} & \multicolumn{2}{|c|}{3} & \multicolumn{2}{|c|}{4} & \multicolumn{2}{|c|}{5} \\
\hline & No. & $\%$ & No. & $\%$ & No. & $\%$ & No. & $\%$ & No. & $\%$ \\
\hline Environment & & & & & & & 9 & 32 & 19 & 68 \\
\hline Flora and Fauna & & & 2 & 7 & 9 & 32 & 10 & 36 & 7 & 25 \\
\hline Landscape & & & 4 & & 4 & $\infty$ & 7 & 25 & 21 & 75 \\
\hline
\end{tabular}




\begin{tabular}{|c|c|c|c|c|c|c|}
\hline Historical heritage & & & & & & 86 \\
\hline Infrastructure & 7 & 25 & 12 & 43 & 8 & \\
\hline Local Traditions & & & & & & 89 \\
\hline Handmade Products & & & & & & 61 \\
\hline Accommodation & 2 & 7 & 7 & 25 & 15 & \\
\hline Transport infrastructure & 4 & 14 & 18 & 64 & 5 & \\
\hline Climate & & & & & 12 & 18 \\
\hline Natural Water Springs & & & & & & 64 \\
\hline Local people attitudes to tourists & & & & & 2 & 39 \\
\hline Sulfur Hot Sand & & & & & & 68 \\
\hline Government investment & 7 & 25 & 12 & 43 & 8 & \\
\hline Health Care & 18 & 64 & 9 & 32 & 1 & \\
\hline
\end{tabular}

1= Poor, 2= Fair, 3= Good, 4= Very Good, 5= Excellent

The survey results explain the assessment of the potential of Curative Tourism in Al-Wadi alJadid Governorate from the viewpoint of tourism stakeholders, are very positive to the natural potential in Al-Wadi al-Jadid Governorate, and very negative to the artificial potential in Al-Wadi al-Jadid Governorate to enhance curative tourism development in the Governorate.

\section{2- The importance of developing curative tourism in Al-Wadi al-Jadid Governorate:}

Table (2) presents the descriptive statistics of respondents' answers regarding the importance of developing curative tourism in Al-Wadi al-Jadid Governorate and its economical, social and environmental impact on the local community of the case study area.

Table (2): Respondents descriptive statistics

\begin{tabular}{|l|l|c|c|c|c|}
\hline \multicolumn{1}{|c|}{ Item } & No. & $\begin{array}{c}\text { Mini. } \\
*\end{array}$ & $\begin{array}{c}\text { Max. } \\
*\end{array}$ & Mean & $\begin{array}{c}\text { Std } \\
\text { Deviation }\end{array}$ \\
\hline $\begin{array}{l}\text { Improve the competitiveness position of } \\
\text { Egypt as a tourism destination in the } \\
\text { international tourism markets. }\end{array}$ & 28 & 3 & 5 & 4,255 & 0,628 \\
\hline Conservation of natural Resources. & 28 & 3 & 5 & 4,244 & 0,567 \\
\hline Conservation of Historical heritage & 28 & 2 & 5 & 3,655 & 0,823 \\
\hline Infrastructural provision. & 28 & 3 & 5 & 4,244 & 0,567 \\
\hline Attract new investment. & 28 & 3 & 5 & 4,155 & 0,578 \\
\hline $\begin{array}{l}\text { Therapeutic and curative tourism } \\
\text { infrastructure. }\end{array}$ & 28 & 3 & 5 & 4,255 & 0,628 \\
\hline Create jobs for the local community. & 28 & 3 & 5 & 4,155 & 0,578 \\
\hline Improvement of social services. & 28 & 2 & 5 & 3,655 & 0,823 \\
\hline $\begin{array}{l}\text { More economic benefits to local } \\
\text { community. }\end{array}$ & 28 & 1 & 5 & 3,933 & 0,909 \\
\hline Retention of traditions and local culture. & 28 & 3 & 5 & 4,155 & 0,578 \\
\hline
\end{tabular}

(*) Likert Scale (1 to 5), Starting with "1" = strongly disagree to "5" = strongly agree. 
According to the respondents answers which shown in table (2), the majority of respondents tend that developing the curative tourism in the case study area, will have a positive impact on economic and social aspects of the local community. As all mean values fall between 3,655 and 4,255 and standard deviation values ranges from 0,567 to 0,909 .

\section{3- Opportunities and Threats of developing curative Tourism:}

To examine the opportunities and threats of developing curative tourism in Al-Wadi al-Jadid Governorate, The questionnaire consisted on some open questions to know the viewpoint of tourism stakeholders about the strengths, weakness of Al-Wadi al-Jadid Governorate as a curative tourism destination and to know the opportunities and threats to develop curative tourism in this area. Responses from interviews with stakeholders and secondary raw data from official documents and reports were prepared for analysis by reading data many times to check for data redundancy, Then coding data to combine closely related categories, Then findings are discussed using SWOT analysis. SWOT matrix determines the strengths and weaknesses, which affect on internal environment of organization, and evaluate threats and opportunities from external environment. So it examines the positive and negative factors inside and outside the organization that affect its success (Wheelen et al, 2015).

A list of internal factors (strengths and weakness) were prepared as shown at table (3), and another list of external factors (opportunities and threats) were prepared according to the respondents answers as shown at table (4). To build the evaluation matrix of internal factors (IFE) and external factors (EFE), the importance of each sub-factor was examined and assigned a weighting score between zeros (insignificant) to one (significant). To calculate the weighted score of each subfactor of IFE and EFE, the weight of each sub-factor multiplied by the weight of normalized factor (Table 3 and 4).

Table (3): Internal Factors Evaluation (IFE) - Strengths and Weaknesses.

\begin{tabular}{|c|c|c|c|c|}
\hline Code & Strengths & Weight & Score & $\begin{array}{l}\text { Weighted } \\
\text { Score } \\
\end{array}$ \\
\hline S1 & - Unpolluted Pure Environment. & 0.058 & 1 & 0.148 \\
\hline $\mathrm{S} 2$ & $\begin{array}{l}\text { - The rich of Sulfur sand and black sand that address some of } \\
\text { the chronic diseases and skin diseases and diseases of the joints } \\
\text { and muscles. }\end{array}$ & .0066 & 1 & 0.244 \\
\hline S3 & $\begin{array}{l}\text { - Natural hot water springs, which have therapeutic healing } \\
\text { effects of many diseases. }\end{array}$ & 0.068 & 1 & 0.268 \\
\hline S4 & $\begin{array}{l}\text { - Dry desert climate Most days of the year and long sunny } \\
\text { days. }\end{array}$ & 0.068 & 2 & 0.164 \\
\hline S5 & - The variety of the natural resources and unique landscapes. & 0.054 & 3 & 0.122 \\
\hline S6 & $\begin{array}{l}\text { - Affordable cost of medical services compared to other } \\
\text { neighboring countries. }\end{array}$ & 0.066 & 1 & 0.212 \\
\hline S7 & $\begin{array}{l}\text { - Potential curative sites are very close to other historical, } \\
\text { archaeological and natural tourist attractions. }\end{array}$ & 0.043 & 1 & 0.268 \\
\hline S8 & $\begin{array}{l}\text { - Easy to be accessed from main cities, as it has } 2 \text { airports in } \\
\text { Kharga City and Dakhla City. }\end{array}$ & 0.068 & 2 & 0.021 \\
\hline S9 & - Unique in social features and rich in its traditional values, & 0.058 & 3 & 0.016 \\
\hline
\end{tabular}




\begin{tabular}{|c|c|c|c|c|}
\hline & culture, art and handicrafts. & & & \multirow{3}{*}{$\overbrace{\substack{\text { Weighted } \\
\text { Score }}}$} \\
\hline \multicolumn{2}{|r|}{ Sub-total } & 0.549 & & \\
\hline Code & Weaknesses & Weight & Score & \\
\hline W1 & - Lack of Health Spa and wellbeing establishments. & 0.062 & 1 & 0.148 \\
\hline W2 & - Lack of high quality hospitals. & 0.043 & 1 & 0.121 \\
\hline W3 & $\begin{array}{l}\text { - Lack of qualified and skilled staff for therapeutic and curative } \\
\text { tourism. }\end{array}$ & 0.043 & 1 & 0.064 \\
\hline W4 & $\begin{array}{l}\text { - Few number of available suitable hotels for accompanying } \\
\text { persons. }\end{array}$ & 0.032 & 3 & 0.05 \\
\hline W5 & - Low quality of the roads which lead to the touristic areas. & 0.036 & 4 & 0.01 \\
\hline W6 & $\begin{array}{l}\text { - The intense heat and storm during summer, which threat } \\
\text { tourism activities during summer. }\end{array}$ & 0.028 & 2 & 0.018 \\
\hline W7 & $\begin{array}{l}\text { - Traditions, handicrafts and habits on their slow way of } \\
\text { disappearance. }\end{array}$ & 0.036 & 3 & 0.05 \\
\hline W8 & $\begin{array}{l}\text { - Increasing of environment pollution due to some industrial } \\
\text { projects and some tourism activities. }\end{array}$ & 0.043 & 3 & 0.148 \\
\hline W9 & $\begin{array}{l}\text { - Lack of private sector investments in the field of therapeutic } \\
\text { and curative tourism. }\end{array}$ & 0.05 & 4 & 0.136 \\
\hline W10 & $\begin{array}{l}\text { - Lack of governmental strong support to promote therapeutic } \\
\text { and curative tourism. }\end{array}$ & 0.046 & 5 & 0.148 \\
\hline W11 & $\begin{array}{l}\text { - Movement of the sand dunes, which threat the roads and } \\
\text { establishments. }\end{array}$ & 0.022 & 2 & 0.016 \\
\hline W12 & - Building some local private hotels without building permit. & 0.01 & & 0.016 \\
\hline & Sub-total & 0.451 & & \\
\hline & Total & 1 & & \\
\hline
\end{tabular}

Table (3) presents the internal factors evaluation (IFE) Al-Wadi al-Jadid Governorate as a curative tourism destination. Strengths and weaknesses factors were analyzed and their proportional influence index was separately determined. Respondents see that the major points of strengths of Al-Wadi al-Jadid Governorate as a curative tourism destination were S3, S7, S2 and S6, which weighted the highest scores. The weakest points in their evaluations were $\mathrm{W} 1, \mathrm{~W} 8, \mathrm{~W} 10$ and $\mathrm{W} 9$, which weighted respectively $0.148,0.148,0.148$, and 0.136 .

Table (4): External Factors Evaluation (EFE) - Opportunities and Threats.

\begin{tabular}{|c|c|c|c|c|}
\hline Code & Opportunities & Weight & Score & $\begin{array}{c}\text { Weighted } \\
\text { Score }\end{array}$ \\
\hline O1 & $\begin{array}{l}\text { - High demand in for healthcare services of the countries } \\
\text { with aging population. }\end{array}$ & 0.098 & 1 & 0.468 \\
\hline $\mathrm{O} 2$ & $\begin{array}{l}\text { - Egypt is an upcoming Curative tourism destination with a } \\
\text { high potential in growth for more than } 370 \text { million } \\
\text { inhabitants in } 22 \text { countries which comprises the Arab } \\
\text { world. }\end{array}$ & 0.098 & 1 & 0.268 \\
\hline $\mathrm{O} 3$ & $\begin{array}{l}\text { - Improving lifestyles move quickly to the demand of } \\
\text { health tourism. }\end{array}$ & 0.068 & 1 & 0.344 \\
\hline $\mathrm{O} 4$ & - Possibility of different types of tourism activities. & 0.054 & 3 & 0.146 \\
\hline O5 & - Possibility to establish some craft centers to protect the & 0.058 & 3 & \\
\hline
\end{tabular}




\begin{tabular}{|c|c|c|c|c|}
\hline & $\begin{array}{l}\text { traditional cottage industries, and to increase the income of } \\
\text { the local people. }\end{array}$ & & & \\
\hline O6 & $\begin{array}{l}\text { - The global trend of protection and sustainability of } \\
\text { natural and cultural values. }\end{array}$ & 0.088 & 2 & 0168 \\
\hline O7 & $\begin{array}{l}\text { - The global trend of developing old town architecture } \\
\text { based on local culture. }\end{array}$ & 0.05 & 2 & 0.018 \\
\hline O8 & $\begin{array}{l}\text { - The global trend of participation of local people in the } \\
\text { production process. }\end{array}$ & 0.033 & 2 & 0.024 \\
\hline \multicolumn{2}{|r|}{ Sub-total } & 0.547 & & \\
\hline Code & Threats & Weight & Score & $\begin{array}{l}\text { Weighted } \\
\text { Score }\end{array}$ \\
\hline T1 & $\begin{array}{l}\text { - Absence of governmental development strategy for } \\
\text { therapeutic and curative tourism in this area. }\end{array}$ & 0.068 & 1 & 0.138 \\
\hline $\mathrm{T} 2$ & - Economic difficulties and global economic downturns. & 0.054 & 3 & 0.146 \\
\hline T3 & $\begin{array}{l}\text { - Increased pressure on the environmental resources due to } \\
\text { intense tourism activity. }\end{array}$ & 0.024 & 3 & 0.146 \\
\hline T4 & - Insufficient of the development of infrastructure. & 0.068 & 1 & 0.248 \\
\hline T5 & $\begin{array}{l}\text { - Degradation of natural curative attractions, which used as } \\
\text { centers of intensive recreational usage, such as walking } \\
\text { areas, picnic areas, camp sites and so on. }\end{array}$ & 0.01 & 1 & 0.132 \\
\hline T6 & $\begin{array}{l}\text { - Lack of institutional support to develop therapeutic and } \\
\text { curative tourism. }\end{array}$ & 0.068 & 1 & 0.246 \\
\hline $\mathrm{T} 7$ & $\begin{array}{l}\text { - The great competition that exists with neighbor countries, } \\
\text { which have good experience in therapeutic and curative } \\
\text { tourism such as Jordan, Tunisia and Dubai. }\end{array}$ & 0.054 & 2 & 0.12 \\
\hline $\mathrm{T} 8$ & $\begin{array}{l}\text { - Insufficient of private local and foreign investments and } \\
\text { governmental funds in tourism investments. }\end{array}$ & .064 & 2 & 0.042 \\
\hline T9 & - Lack of infrastructure in most villages. & 0.043 & 4 & 0.012 \\
\hline & Sub-total & 0.453 & & \\
\hline & Total & 1 & & \\
\hline
\end{tabular}

Table (4) presents the external factors evaluation (EFE) for Al-Wadi al-Jadid Governorate as a curative tourism destination. Opportunities and threats factors were analyzed and their proportional influence index were separately determined. Respondents see that the major points of opportunities which affect on the potential of Al-Wadi al-Jadid Governorate as a curative tourism destination were $\mathrm{O} 1, \mathrm{O} 3$ and $\mathrm{O} 2$, which weighted respectively $0.468,0.344$ and 0.268 . The major threats points in their evaluations were T4, T6, T2 and T3, which weighted respectively $0.248,0.246,0.146$ and 0.146 .

All sub-factors of internal strengths and weakness and all sub-factors of external opportunities and threats were examined and compared to get 4 types of strategies, weaknesses with opportunities (WO- Mini-Maxi Strategy), strategy that Leverage opportunities and strengths to resolve the weakness; strengths with opportunities (SO Maxi-Maxi Strategy), strategy that leverages strengths to maximize opportunities; strengths with threats (ST-Maxi-Mini Strategy), strategy that leverages strengths to minimize threats; and weaknesses with threats (WT- Mini-Mini Strategy), strategy that minimizes both weaknesses and threats ( Gomatesh and Poornima, 2012 ). These 4 types of strategies will build a final matrix of Curative Tourism Development Strategy for Al-Wadi al-Jadid Governorate (Table 5).

Table (5) Matrix of Curative Tourism Development Strategy for Al-Wadi al-Jadid Governorate 


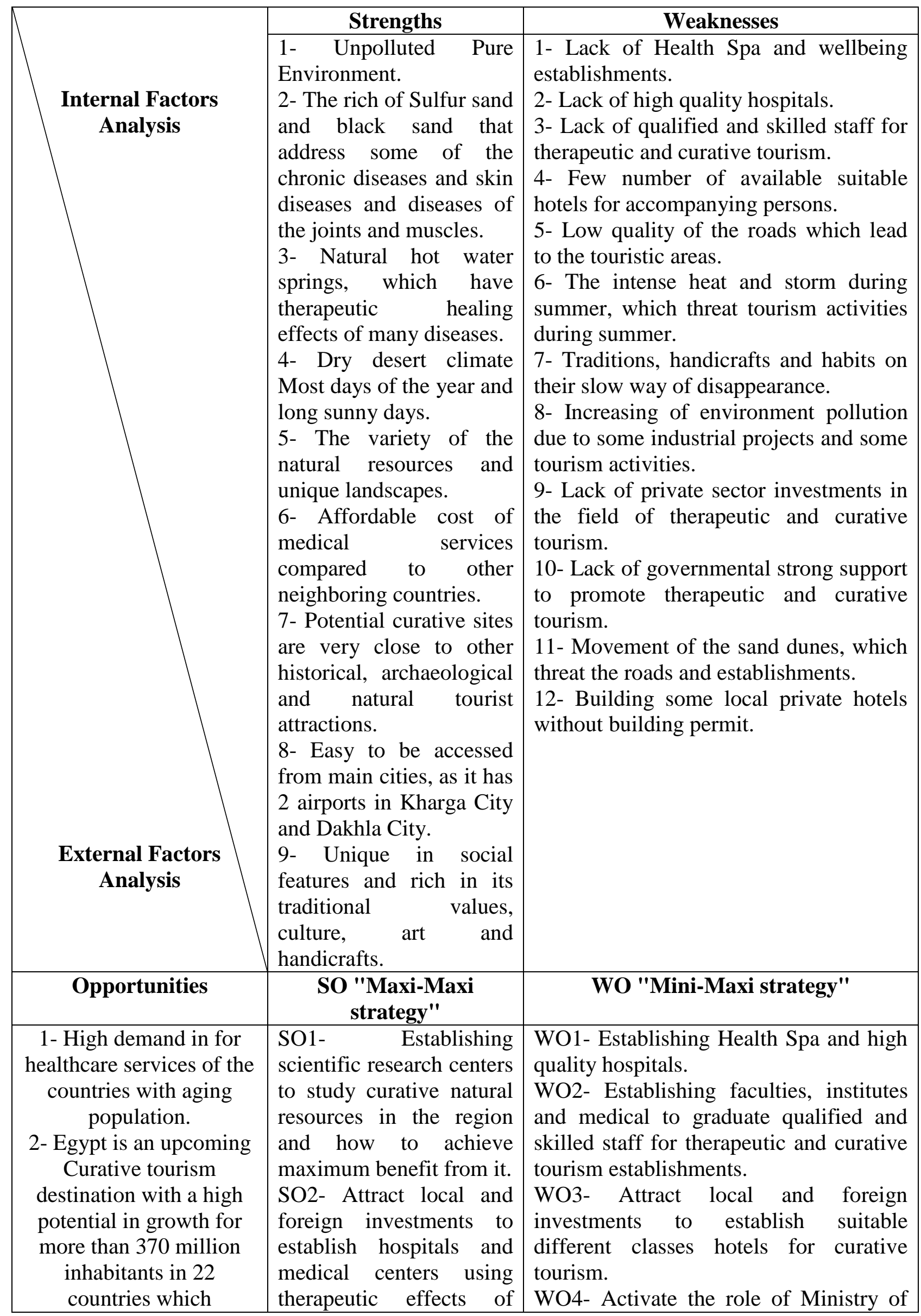


comprises the Arab world.

3- Improving lifestyles move quickly to the demand of health tourism.

4- Possibility of different types of tourism activities.

5- Possibility to establish some craft centers to protect the traditional cottage industries, and to increase the income of the local people.

6- The global trend of protection and sustainability of natural and cultural values.

7- The global trend of developing old town architecture based on local culture.

8- The global trend of participation of local people in the production

\begin{tabular}{|c|}
\hline process. \\
\hline Threats \\
\hline $\begin{array}{l}\text { 1- Absence of } \\
\text { governmental }\end{array}$
\end{tabular}

development strategy for therapeutic and curative tourism in this area.

2- Economic difficulties and global economic downturns.

3- Increased pressure on the environmental resources due to intense industrial and tourism activity.

4- Insufficient of the development of infrastructure.

5- Degradation of natural curative attractions, which used as centers of intensive recreational usage, such as walking many natural resources . SO3- Create a special brand for Al-Wadi AlJadid Curative Tourism Product.

SO4- Take all necessary actions to get in contact with international organizations, which are interested in protection and sustainability of natural and cultural values.

SO5- Upgrade the main two airports of Al-Wadi Al-Jadid Governorate, in Kharga City and Dakhla to be able to receive international flights.

SO6- Establishment of craft centers to protect the traditional cottage industries.
Culture and Ministry of Environment in preserving traditions, handicrafts and habits of Al-Wadi al-Jadid local people.

WO5- Contact research centers, universities and international institutes to solve the problem of heat, storm and sand dunes during summer, which threat tourism activities during summer. 


\begin{tabular}{|c|c|c|}
\hline $\begin{array}{l}\text { areas, picnic areas, camp } \\
\text { sites and so on. } \\
\text { 6- Lack of institutional } \\
\text { support to develop } \\
\text { therapeutic and curative } \\
\text { tourism. } \\
\text { 7- The great competition } \\
\text { that exists with neighbor } \\
\text { countries, which have } \\
\text { good experience in } \\
\text { therapeutic and curative } \\
\text { tourism such as Jordan, } \\
\text { Tunisia and Dubai. } \\
\text { 8- Insufficient of private } \\
\text { local and foreign } \\
\text { investments and } \\
\text { governmental funds in } \\
\text { tourism investments. } \\
\text { 9- Lack of infrastructure } \\
\text { in most villages. }\end{array}$ & $\begin{array}{l}\text { region. } \\
\text { ST4- Create a strong } \\
\text { desire for the government } \\
\text { to develop therapeutic } \\
\text { tourism in Al-Wadi al- } \\
\text { Jadid to create a } \\
\text { distinctive Egyptian } \\
\text { curative tourism product. } \\
\text { ST5- Exploitation of the } \\
\text { natural resources of Al- } \\
\text { Wadi al-Jadid as a } \\
\text { competitive advantage to } \\
\text { face the competition with } \\
\text { neighbor countries, } \\
\text { which have good } \\
\text { experience in therapeutic } \\
\text { and curative tourism. }\end{array}$ & $\begin{array}{l}\text { their local traditions, habits and } \\
\text { handicrafts from disappearance. }\end{array}$ \\
\hline
\end{tabular}

\section{Conclusion:}

Evidence indicates that, despite is a great potential for developing curative tourism in Al-Wadi alJadid Governorate, which related to the diversified natural curative resources such as mineral hot water springs, sulfur and black sand, dry desert climate, unpolluted pure environment and so on, Al-Wadi al-Jadid has no curative tourism product, or a clear vision and tourism strategies concerning developing curative tourism.

The infrastructure and superstructure in Al-Wadi al-Jadid Governorate has a lot of negative aspects, which the Egyptian government must deal with, as it hinder the development of curative tourism in the area, also more governmental support is needed, encouraging tourism investments, developing the infrastructure, superstructure related to health sector and cooperative action plan to promote curative tourism.

SWOT analysis reflects there are some threats that could result from the current tourism development system in Al-wadi al-jadid governorate, such as degradation of attractive landscapes, Erosion of indigenous cultures and Increased pressure on the environmental resources due to intense tourism activity. Also to maximize the benefits of curative tourism in the study area, it's essential to reconsider the tourism policies in Al-Wadi al-Jadid Governorate, especially from the environmental aspects, marketing, investment and development, with concentrating on the sustainability of development.

\section{References:}

- Ababneh, A. (2017), "Background and perspectives of medical and health tourism in Jordan", Yarmouk University, Jordan.

- Ayad, T. (2008), "The Geographical Features of al-Wadi al-Gadid Governorate and its role in varying the Egyptian Tourism Product", Master Thesis, Suez Canal University. 
- Danida for Denmark's development cooperation; State Ministry of Environment, and New Valley Governorate. (2007), "Environmental profile of the New Valley Governorate", Egypt.

- Egypt State Information Service [Online]. Retrieved Aug 20, 2017, from http://www.sis.gov.eg/En

- Egyptian Tourism Authority, (2018), "Menaville Resort \& Spa in Safaga", [Online]. Retrieved Feb 04,2018, from: http://www.egypt.travel/attractions/menaville-resort-spa-in-safaga/

- Gahlinger, PM. (2008), "The Medical Tourism Travel Guide: Your Complete Reference to Top-Quality, Low-Cost Dental, Cosmetic, Medical Care \& Surgery Overseas", Sunrise River Press, USA.

- Gomatesh, M. R. and Poornima. M. Ch. (2012), "Strategic formulation using TOWS Matrix - A Case study", International Journal of Research and Development, Volume 1, Issue 1, India.

- Harahsheh, S. S. (2002), "Curative Tourism in Jordan and Its Potential Development", MA in European Tourism Management (ETM) Bournemouth University, United Kingdom.

- Hoobin,Y. B. (2011), "Motivation and experiences of mainland Chinese medical tourists in Hongkong", Tourism Management, Volume 32, Issue 5, October 2011, Pages 1125-1127.

- Ildoromi, A. and Sefidi, Z. (2011), "Study of the Awareness and Perspectives of Hospital Staff Working at Ghazvin Pre-provinces Hospitals Regarding Curative Tourism in 2010", First Conference on Tourism and Sustainable Development, Azad University of Hamedan, Iran.

- Joint Commission International, (2018), "Top 10 Medical Tourism Destinations", by MEDIGO GmbH, Berlin, Germany. [Online]. Retrieved Feb 04,2018, from:

https://www.medigo.com/blog/medical-tourism/top-10-healthcare-destinations/

- Medical Tourism Association, (2017), "2017 Monitoring Medical Tourism Trends", issued by VISA and Oxford Economics, USA. [Online]. Retrieved Feb 04,2018, from: https://www.medicaltourismindex.com/2016-medicaltourism-industry-valuation/

- Medical Tourism Association, (2018a), "Popular medical tourism destination in the Middle East", by Dr. Prem Jagyasi, USA. [Online]. Retrieved Feb 04,2018, from: http://www.medicaltourism.com/blog/popular-medicaltourism-destination-in-the-middle-east/

- Medical Tourism Association, (2018b), "Egypt Medical Tourism Index", by MTI, USA. [Online]. Retrieved Feb 04,2018, from:

https://www.medicaltourismindex.com/destination/egypt/

- Ministry of Planning, (2017), "Citizen guide for the investment plan in the new Valley 2016/2017", Arab Republic of Egypt.

- New Valley Governorate website [Online]. Retrieved Sep 15, 2017, from: http://www.newvalley.gov.eg

- Patients Beyond Borders [Online]. Retrieved Feb 04, 2018, from:

http://www.patientsbeyondborders.com/medical-tourism-statistics-facts

- Rouhollah, I. and Dirin, Y. ( 2013 ), "Effect of hot mineral waters on the health tourism development in Meshkinshahr city", Academic Journal of Research in Economics \& Management, Vol. 1, No. 4, December 2013.

- Skowron, L. and Sak-Skowron, M. (2014), "Opportunities and challenges of medical tourism", The Macrotheme Review 3(1)A, Spring 2014.

- State Ministry of Environment and New Valley Governorate. (2008), "Environmental action Plan: New Valley Governorate", Egypt.

- State Ministry of Environment and New Valley Governorate. (2017), "Status of the Environment in Egypt 2015", 2017 issue, Egypt. 
- Wheelen, L. T; Hunger, D. J.; Hoffman, N. A. and Bamford, E. C. (2015), "Concepts in Strategic Management and Business Policy", Pearson Education, New Delhi, Fourteenth Edition.

- Wikimedia Commons [Online]. Retrieved Oct 25, 2017, from:

https://commons.wikimedia.org/wiki/File:Egypt,_administrative_divisions_-_de_-_colored.svg

- The World Bank. (2017), "Jordan Emergency Health Project", Report No: PAD2370, International bank for reconstruction and development, Middle East And North Africa Region. 